\title{
Developing Legal Conscious Behavior on Implementing Protocol of Health Covid-19 in Pekanbaru
}

\author{
Roby Rahman ${ }^{1, *}$ Dadang Sundawa ${ }^{2,}$ Iim Siti Masyitoh ${ }^{3}$ \\ ${ }^{1,2,3}$ Universitas Pendidikan Indonesia \\ *Corresponding author.Email: ro_bey@upi.edu
}

\begin{abstract}
Coronavirus 2019 or COVID-19 is a pandemic that has resulted in high mortality rates in various parts of the world. Good knowledge about the COVID-19 pandemic and clean and healthy living behavior as an effort to prevent the transmission of COVID-19 is important to implement. This study will examine how a Pekanbaru Mayor Regulation can accommodate efforts to build community legal awareness in implementing the Covid-19 health protocol, where the focus of the study is carried out in Pekanbaru City through the formation of Pekanbaru Mayor Regulation Number 160 of 2020 concerning Guidelines for Micro-Scale Social Restrictions. In Certain District Areas in the Prevention and Control of Corona Virus Disease 2019 in Pekanbaru City. This study uses a qualitative research approach with descriptive methods. This study uses interviews, observation and documentation analysis as a data collection tool. Through observations made by researchers in the field, it was found that the community has not fully implemented the Covid-19 health protocol. In order for the implementation of the Covid-19 health protocol to run optimally in accordance with the mandate of Pekanbaru Mayor Regulation Number 160 of 2020, efforts are needed to build legal awareness. What the Pekanbaru City government can do in this case is the Covid-19 task force in various forms, both socialization, raids and various other socializations. It is also necessary to place guard posts in markets and other crowded places so that the handling of the COVID-19 pandemic is more effective. Field workers must control every hour to ensure that residents who are in the market or in other crowded places practice the $5 \mathrm{M}$ (Wear masks, Wash hands with soap and running water, Maintain distance, Stay away from crowds, Limit mobilization and interaction).
\end{abstract}

Keywords: Building Public Legal Awareness, Covid-19 Health Protocols, Legal Awareness

\section{INTRODUCTION}

End of 2019, world stirred up by new epidemic Corona virus (SARS-COVID 2) known by Corona Virus Disease (COVID 19). Virus came from Wuhan, Hubei Province, Country of China. In the end of December 2019 (Yuliana in PDPI. 2020). This virus has been spread around the world. This virus could transmit both of humans (Aditya Susilo and friends in WHO Report. 2020). Panic happened in Indonesia, after its President announced Covid-19 case in 2nd March 2020. Its became the first and the second cases in Indonesia.

Antony de Mello said for handling pandemic in the world, the case could be five times increased if there was panic. A thousand people became sickness victims, in otherwise four thousand became of panic victims (Mello. 1992). Because of that, tranquility and firmness required, in facing this case.

The increasing numbers cause many aspects, such as economy, social, culture, well-being society. Because of that, required tight action in handling and avoid increasing of Covid 19. Less of citizen awareness, make this epidemic increase. In first observation, the observer found some problems in location. Such as, most of citizen disobey protocol of health, related to $5 \mathrm{M}$, namely :

1) Wear masks

2) Wash hands use soap and flowing water

3) Keep distance

4) Keep away crowds

5) Limit mobilization and interaction

Observer met the sellers and buyers in Panam market, cik puan market, pasar pagi arengka. Most of them, use masks when there was patrol's inspection. Therefore in certain times, the inspections in some spots. But, short inspections durations make riders don't use their masks. Mostly, they put their masks in their necks.

Effectively, because of its increasing need hard punishment to minimize Covid-19 case in Indonesia. Because of Covid-19 is new virus, the solutions should learned. Prevention strategy trough isolation, predetection, based protection. (Aditya Susilo \& friends in, 
General Directorate of Control and Disease Prevention. 2020).

\section{LITERATURE REVIEW}

\subsection{Develop Legal Conscious Behavior}

According to Soerjono Soekanto (1977) legal conscious is abstract conception inside human being, about harmony between orderliness and tranquility that wished.

Indicators of legal conscious problems (Soerjono Soekanto,1977, Page 159), they are :

a. Law awareness

b. Law acquaintance

c. Legal attitude

d. Legal behavior

Theory of moral development, according to Kohlberg, there are three level as follow :

\section{Pre conventional}

Pre conventional is the lowest level in Kohlberg's moral development theory. In this level, children do not show internalization moral values. Moral reasoning is controlled by external present and punishment. In other word, doing something is caused by a will good reputed.

2. Conventional

Conventional is middle individual internalization level where someone obey specific standard (internal), but they do not obey other standard (external) like parents or society law. In other word, doing something is because of fear of threat.

3. Post conventional

Post conventional is high level of thinking where moral is actually internalized and not based on other standard. Someone introduce alternative moral actions, probe choice, and then decide based on code. In other word, doing something is because he/she regards the law is important.

\subsection{Covid-19}

Covid-19 is infect disease that is caused by new corona virus species. Before it epidemic in Wuhan, Tiongkok, December 2019. The virus is not absolutely identified. Now, Covid-19 becomes a pandemic in most countries in the world. (World Health Organization, 2020). In Indonesia, its appeared in early March 2020.

Coronavirus is big family virus that caused disease to human and animal. Usually in human, it causes respirations like infection, started from usual flu until serious disease like Middle East Respiratory Syndrome (MERS) and Severe Acute Respiratory Syndrome (SARS). The new coronavirus species case found at last December 2019, appeared in Wuhan, China. Its called Severe Acute Respiratory Syndrome Coronavirus 2
(SARS-COV 2 ), and causes coronavirus disease 2019 (Covid-19) (Kemenkes RI. 2020)

\subsection{Protocol of Health (Motion 5 M)}

To break link of spreading coronavirus, firstly Indonesia Government campaign $3 \mathrm{M}$ and $3 \mathrm{~T}$ motion, namely keep distance, wear masks, wash hands and testing, tracing, treatment. Government role is to campaign $3 \mathrm{~T}$, but $3 \mathrm{M}$ in society role. BPS survey, in September 2020 , it report $74 \%$ people that already obey the rule. But now, the law is changed to $5 \mathrm{M}$ and $3 \mathrm{~T}$. The term of $5 \mathrm{M}$, the explanation as follow:

1. Wear masks, you are hope to wear mask when you are outdoor, or when you assemble with your family wherever.

2. Wash hands, you should hands use flowing water and soap period. If there is not water and soap, you can use hand sanitizer to clean hands from microbe.

3. Keep distance. if there is urgent utility that make you should go out, remember to keep distance from other people. The distance suggested 1 until 2 meters from others.

4. Keep away crowds, you are required to keep away crowds when you are out door. Remember, more people you meet, more corona infection that affected you.

5. Limit mobilization, if there is not urgent utility, you stay at home. Although safe and there is no indication of disease, it's not indicate that you arrive at home safely or healthy.

\section{METHODOLOGY}

The approach in this study, using a qualitative approach. Besides that, Loncold and Guba see qualitative research as naturalistic research. This research departs from the naturalistic paradigm, that 'reality is plural, the researchers studied are interactive, inseparable, a unity is formed simultaneously and reciprocally, it is impossible to separate cause and effect in this research involves values [22]. In this study, the research design used ethnographic methods. According to Creswell, ethnographic research is a qualitative procedure for describing, analyzing, and interpreting the same patterns in the behavior, beliefs, and language of a cultural group, which develop over time. In ethnography, the researcher provides a detailed description of the culturally-sharing groups based on various sources of information [23]. Robert H. Lowie (in Mulyadi, et al, said that ethnography is "... Ethnography is the which deals with the culture of human groups. It is that part of anthropology (in the English sense of the world, the whole science of man)." or ethnography is part of anthropology and the main study is culture [24]. 
This study focuses more on a qualitative approach with an ethnographic research design method, which facilitates researchers to describe, analyze and understand naturally and comprehensively the local wisdom of the saprah tradition as a source of Civics learning that is reflects the three citizenship skills (civic knowledge), (civic disposition), and (civic skills) Techniques The data collection in this study used the techniques of 1) observation, 2) interviews; 3) Documentation; and (4 Triangulation. While the data analysis technique in this study, uses qualitative data analysis interactive models). Which consists of three activities, occurring simultaneously, namely 1) Data reduction, 2) Data presentation, 3) Drawing conclusions/Verification.

\section{RESULT AND DISCUSSION}

According to researchers, legal awareness will arise because there are several factors, including the first is a disaster factor, if one of their family members is affected by a disaster in this case is affected by the corona virus, then members from other families will realize the importance of maintaining health protocols. They will be more careful and will try to keep wearing masks and keep the $5 \mathrm{M}$. Then the second awareness that must be forced, there is a phrase that says that it is forced, forced, then you can, then you get used to it until it becomes a culture. There are times when the rule of law, in order to realize a good desire, a policy is made that forces a person or group of people to obey the rule of law. For example, in India, in the first wave of covid, they managed to reduce the spread of cases by forcing officers to not even hesitate to beat their citizens who were found to be active outside their homes, except in emergency conditions.

Finally, within 2 months after the lockdown, India managed to drastically reduce Covid-19 cases. although in the second wave (covid second wave) India was overwhelmed after the Ganges River incident. Then the third is awareness with a touch of religion, making posters or billboards with slogans reminding that cleanliness is part of faith, because apart from being beneficial for health, it also gets a reward. Of course, for Muslims, they already understand and understand the guidelines for maintaining cleanliness because we are told to maintain ablution at least every 5 times, but humans often make mistakes and forget, so it is necessary for preachers and mosque administrators to always remind the congregation and the public to always take care of themselves. cleanliness, because obeying the rules as long as the rules do not deviate from the Shari'a, then it is an obligation for believers to obey them.

\section{CONCLUSION}

In fact, in society it is classified in terms of legal awareness, some are aware of the importance of the health protocol based on an understanding of religion. Because they think that the calamity is destiny from God, the calamity will always exist from time to time from the time of ignorance until now. Some think because they want to be healthy, so they obey government rules. There are also those who think that this pandemic is engineered by the globalist elite. Therefore, the researcher's assumption is that awareness arises because the disaster factor and the effort go hand in hand, so in dealing with the case of the covid pandemic, it is necessary to involve all components of society to work together in realizing the desire to be free from the covid-19 pandemic The bottom line is that one of the virtues of citizenship is awareness of disasters and having the will and ability to be involved in overcoming the COVID-19 pandemic.

\section{REFERENCES}

[1] Al Muchtar, S. (2015). Dasar Penelitian Kualitatif. Bandung: Gelar Pustaka Mandiri

[2] Branson, M. S. (1999). Belajar Civic Education dari Amerika. Yogyakarta: Lembaga Kajian Islam Dan Sosial (LkiS) dan The Asia Foundation (TAF).

[3] Budimansyah, D. (2008). Pembelajaran Pendidikan Kesadaran Hukum. Bandung: PT. Genesindo

[4] Wahab, A. A dan Sapriya. (2011). Teori dan Landasan Pendidikan Kewarganegaraan. Bandung: Alfabeta

[5] Zubaidi. (2006). Pendidikan Berbasis Masyarakat Upaya Menawarkan Solusi Terhadap Berbagai Problem Sosial. Yogyakarta: Pustaka Pelajar.

[6] Arditama, Erisandi, and Puji Lestari. 2020. “Jogo Tonggo : Membangkitkan Kesadaran Dan Ketaatan Warga Berbasis Kearifan Lokal Pada Masa Pandemi Covid-19 Di Jawa Tengah." Jurnal Pendidikan Undiksha $\quad 8(2)$ : 157-67. https://ejournal.undiksha.ac.id/index.php/JJPP.

[7] Januar Mahardhani, Ardhana. 2020. "Menjadi Warga Negara Yang Baik Pada Masa Pandemi Covid-19: Persprektif Kenormalan Baru.” Jurnal Pancasila dan Kewarganegaraan 5(2): 65-76.

[8] Kusuma, E. D. (2021). Penerapan Sanksi Pelanggar Physical Distancing Dan Penggunaan Masker Berdasarkan Perwali Batu Nomor 78 Tahun 2020. Dinamika: Jurnal Ilmiah Ilmu Hukum, 27(6), 876889.

[9] Mathew, Sarah, Robert Boyd, Sarah Mathew, and Robert Boyd. (2014). "Punishment Sustains LargeScale Cooperation in Prestate Warfare." (May). 
[10] Remaja, Perilaku Menyimpang et al. (2018). "Bentuk-Bentuk Sanksi Sosial Masyarakat Terhadap Perilaku Menyimpang Remaja.” 3(1): 24315 .

[11] John Kenedi. (2002). "Studi Analisis Terhadap Nilai?Nilai Kesadaran Hukum Dalam Pendidikan Kewarganegaraan (Civic Education) Di Perguruan Tinggi Islam."

[11] Belladona, Aprilio Poppy. (2013). Pendidikan Kewarganegaraan Sebagai Wahana Dalam Meningkatkan Kesadaran Hukum Mahasiswa. Tesis Pada Jurusan Pendidikan Kewarganegaraan SPs UPI Bandung: Tidak Diterbitkan

[12] Fitriasari, S. (2008). Proses Pendidikan Hukum Pada Lembaga Pemasyarakatan Dalam Membina Warga Negara Yang Baik. Tesis pada FPIPS Pendidikan Kewarganegaraan UPI Bandung: tidak diterbitkan

[13] Syaifullah. (2025). Pemberdayaan Generasi Muda Sebagai Dasar Filosofis Dari Keterlibatan Warganegara (Civic Engagment): Tinjauan Tentang Programa Mahasiswa Wirausaha (PMW), dalam "Pengauatan Komitmen Komunitas Akademik dalam Memperkokoh Jatidiri PKn". Bandung: Laboratorium

[14] Winarno. (2011). Proses Penerapan Habituasi Melalui Pendidiakan Keewarganegaraan Untuk Menumbuhkan Kesadaran Hukum. Tesis pada Program Studi Pendidikan Kewarganegaraan UPI Bandung: tidak diterbitkan

[15] Wulan Sari, Yussi Retna. (2013). Pengaruh Status Sosial Ekonomi Keluarga Terhadap Tanggung Jawab Sosial Warga Negara. Tesis pada Program Studi Pendidikan Kewarganegaraan UPI Bandung: tidak diterbitkan

[16] Undang-Undang Dasar 1945 Bab X tentang Warga negara

[17] Peraturan Pemerintah RI. Peraturan Nomor 21 Tahun 2020 tentang Pembatasan Sosial Berskala Besar dalam rangka Percepatan Penanganan Corona Virus Disease (COVID-19).

[18] Keputusan Presiden. Keputusan Presiden Nomor 11 Tahun 2020 tentang Penetapan Kedaruratan Kesehatan Masyarakat Corona Virus Disease (COVID-19)

[19] Walikota Pekanbaru. Undang Undang Nomor 104 Tahun 2020 Tentang Pedoman Perilaku Hidup Baru Masyarakat Produktif Dan Aman Dalam Pencegahan Dan Pengendalian Corona Virus Disease 2019 (Covid-19).

[20] Soerjono Soekanto. (2002). Kesadaran Hukum Dan
Kepatuhan Hukum. Jakarta : Raja Grafindo Persada.

[21] Marwan Mas. (2014). Penghantar Ilmu Hukum.

Bogor :Penerbit Ghaila Indonesia

[22] Sudikno Mertokusumo. (1981). Menigkatkan Kesadaran Hukum Masyarakat. Yogyakarta.

[23] Otje Salman. (1993). Kesadaran Hukum Masyarakat Terhadap Hukum Waris. Bandung. 